\title{
Coral injuries caused by Spirobranchus opercula with and without epibiotic turf algae at Curaçao
}

\author{
Bert W. Hoeksema ${ }^{1,2}\left[\right.$ Dagmar Wels ${ }^{1} \cdot$ Roeland J. van der Schoot $^{1} \cdot$ Harry A. ten Hove ${ }^{1}$
}

Received: 11 January 2019 / Accepted: 26 March 2019 / Published online: 9 April 2019

(c) The Author(s) 2019

\begin{abstract}
Reef-dwelling Christmas tree worms (Spirobranchus spp.) are common coral associates. Their calcareous tubes are usually embedded in the coral skeleton and can be closed by an operculum. Tubes not overgrown by coral tissue either remain bare or become covered by algae. Despite their widespread distribution, high abundance and striking appearance, little is known about the impact of these worms on their hosts. We quantified visible coral damage caused by Spirobranchus in Curaçao (Southern Caribbean) and found that $62.6 \%$ of worm opercula $(n=1323)$ caused abrasions and tissue loss in their hosts. Filamentous turf algae, known to be potentially harmful to corals, covered $76.9 \%$ of the opercula. Examination of the six most frequently inhabited host species showed a variation in the damage percentages, although this was independent of the presence of epibiotic algae on $78.4 \%$ of all opercula. Since injured corals are more susceptible to diseases, the overall negative impact of Spirobranchus worms on their hosts may be more severe than previously assumed.
\end{abstract}

\section{Introduction}

Coral-dwelling tubeworms of the genus Spirobranchus (Polychaeta: Serpulidae), known popularly as Christmas tree worms because of their twin-conispiral branchiae, are commonly found on coral reefs. They live as associates of a large number of host coral species, on which they can form aggregations (Hunte et al. 1990; Hoeksema and Ten Hove 2017a; Hoeksema et al. 2017; Martin and Britayev 2018). Their planktonic larvae usually settle on abraded coral surface (Hutchings 1986) and, more occasionally, on rubble and shells of giant clams (Nygaard 2008; Van der Schoot et al. 2016). The calcareous worm tube is usually overgrown by the host coral and remains embedded within its coral skeleton, except for its opening (Hoeksema and Ten Hove 2014). In this way, the worms can survive over 40 years (Nishi

Responsible Editor: L. Mydlarz.

Reviewed by E. Kupriyanova and D. Martin.

Bert W. Hoeksema

bert.hoeksema@naturalis.nl

1 Taxonomy and Systematics Group, Naturalis Biodiversity Center, P.O. Box 9517, 2300 RA Leiden, The Netherlands

2 Institute of Biology Leiden, Leiden University, PO Box 9505, 2300 RA Leiden, The Netherlands and Nishihira 1996), even if the host becomes overgrown by sponges and octocorals, which in turn can act as replacement hosts (Hoeksema et al. 2015, 2016; García-Hernández and Hoeksema 2017).

When threatened, the worms rapidly retract inside their tubes, closing them by the calcified operculum, which is attached to a fleshy stalk (Hoeksema and Ten Hove 2014; Pezner et al. 2017). Failing to retract in time entails risk of predation by fish (Nishi and Kikuchi 1996; Hoeksema and Ten Hove 2017b). Probably as extra protection, many Christmas tree worms have a sharp spike on the margin of their tube opening as illustrated by Hoeksema et al. (2017: Fig. 1) and antler-shaped spines on their operculum (Hoeksema and Ten Hove 2014: Fig. 1). Moreover, the operculum may become covered by various kinds of epibionts, such as algae, corals, sponges and other serpulids (Hoeksema et al. 2018; Perry et al. 2018a).

The presence of Spirobranchus can be of disadvantage to the host corals when incorporated tubes undermine the structural integrity of corals, causing them to break more easily (Hutchings 2011). Dead worms leave empty holes behind, which can become inhabited by cryptofauna (e.g., hermit crabs, fish) and turf algae (Schuhmacher 1977; Hutchings 1986; Clarke and Tyler 2003; Böhm and Hoeksema 2017), which may prevent corals to regenerate and heal. Spirobranchus worms can also irritate and stress the surrounding polyps (Borger 2005; Hoeksema et al. 2018, 
2019) and even smother and kill their hosts when they occur in high densities (Samimi Namin et al. 2010).

In fact, the opercula can serve as a substrate for epibiotic turf algae and, when the worms are extended, opercula with or without algae can cause damage to the coral surface, as demonstrated in Indo-Pacific reefs (Hoeksema et al. 2018, 2019). Turf algae are known to cause stress and partial mortality in corals (McCook et al. 2001; Vermeij et al. 2010; Longo and Hay 2017). Therefore, we surveyed reefs at Curaçao to assess whether Spirobranchus could be harmful to Caribbean host corals with special emphasis on the possible involvement of opercula and the relationship with epibiotic turf algae on the opercula. Additionally, we analysed whether damage varied among host species.

\section{Materials and methods}

Fieldwork on worm-inflicted coral injuries took place in February-March 2015 on fringing reefs along the leeward coast of Curaçao. The presence of worms on their host corals was recorded by scuba diving in belt transects, each $30 \mathrm{~m}^{2}$ in surface area $\left(n_{\text {tot }}=52.8\right)$. The records were from four different sites (Sites 1-4) that were at least $10 \mathrm{~km}$ apart (Fig. 1), and at 5,10, and $15 \mathrm{~m}$ depth (Table 1). The worms and their hosts were photographed to document damages visible as tissue discoloration or loss on the adjacent coral surface. Only worms for which could be determined that their opercula were harmful or not were included in the analyses (i.e., 1323 of the total number of 2625 worms found; Table 2). In the remaining 1302 cases, damages were not determined either due to the critical spot where an operculum may touch the coral surface being obscured by worm's branchiae or by the coral's tentacles, but also by a wrong

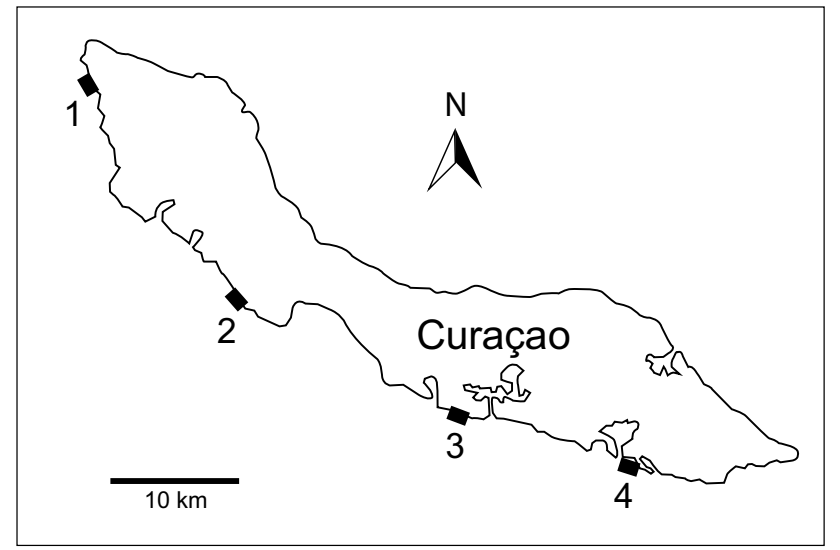

Fig. 1 Reef sites at Curaçao used to survey coral damage caused by Spirobranchus. $1=$ Playa Kalki, $12^{\circ} 22^{\prime} 30^{\prime \prime} \mathrm{N} 69^{\circ} 09^{\prime} 28^{\prime \prime} \mathrm{W} ; 2=$ Daaibooi, $12^{\circ} 12^{\prime} 43^{\prime \prime} \mathrm{N} \quad 6^{\circ} 05^{\prime} 06^{\prime \prime} \mathrm{W} ; 3=$ Water Factory, $12^{\circ} 06^{\prime} 33^{\prime \prime} \mathrm{N}$ $68^{\circ} 57^{\prime} 15^{\prime \prime} \mathrm{W} ; 4$ = Director's Bay, 12 $2^{\circ} 03^{\prime} 58^{\prime \prime} \mathrm{N} 68^{\circ} 51^{\prime} 36^{\prime \prime} \mathrm{W}$
Table 1 Number of $30-\mathrm{m}^{2}$ transects $\left(n_{\text {tot }}=52.8\right)$ and worms $\left(n_{\mathrm{tot}}=1323\right)$ used for the analysis distributed over four sites and three depths

\begin{tabular}{cll}
\hline & Transects $(n)$ & Worms $(n)$ \\
\hline Site & & \\
Site 1 & 18.5 & 270 \\
Site 2 & 12.0 & 409 \\
Site 3 & 10.0 & 382 \\
Site 4 & 12.3 & 262 \\
Depth & & \\
$5 \mathrm{~m}$ & 16.8 & 416 \\
$10 \mathrm{~m}$ & 18.0 & 452 \\
$15 \mathrm{~m}$ & 18.0 & 455 \\
\hline
\end{tabular}

The four sites are not similar in the number of worms $\left(\chi^{2}=51.902\right.$; $p<0.05)$ but the three depths are $\left(\chi^{2}=2136 ; p>0.05\right.$; chi square for goodness of fit)

angle of the pictures. Even though many encountered coral colonies hosted more than one worm, each specimen of Spirobranchus was counted as representing a single association (Table 2). Host corals were identified based on Humann and DeLoach (2013) and the identity of the Spirobranchus specimens was confirmed according to Ten Hove (1970) and partly verified by the last author.

The six most frequently encountered host species, each harbouring $>50$ worms, were selected to analyse the interspecific variation in the occurrence of damages; only 1150 worms of these six species together could be used in the analysis (Table 2). The mean number of worms per host coral colony varied from 1.4 to 3.9 among these six species (Table 2). Damage variability among host species, as well as the relationships between opercula with and without algae and damages, was examined with the Fisher's exact test of independence in $R$ (McDonald 2014). Coral damage caused by algae on worm tubes was not quantified because the latter were unequally embedded in the coral, so that the exposed parts varied much in size (Fig. 2).

\section{Results}

Twenty-one host coral species were infested by Christmas tree worms, all of them belonging to Spirobranchus giganteus (Pallas, 1766) (Table 2). Worm tubes showed various degrees of coral overgrowth (Fig. 2a), including some not overgrown that were situated in depressions on the colony surface, suggesting that coral growth had slowed down beneath and around them (Fig. 2c, d). Exposed tubes could become covered by crustose coralline algae (Fig. 2b) or filamentous turf algae, which harmed the coral surface alongside the tubes (Fig. 2d, e). 
Table 2 Coral species acting as host for Spirobranchus giganteus at Curaçao, with for each: numbers of host coral colonies, worms present, occurrence and absence of distinct damage, total analysed, and unknowns

\begin{tabular}{|c|c|c|c|c|c|c|c|}
\hline Host species & $\begin{array}{l}\text { Host coral } \\
\text { Colonies, } n\end{array}$ & $\begin{array}{l}\text { Worms } \\
\text { Present, } n\end{array}$ & $\begin{array}{l}\text { Mean } \pm \text { SD } \\
n / \text { host coral }\end{array}$ & $\begin{array}{l}\text { Total } \\
\text { Analysed, } n\end{array}$ & $\begin{array}{l}\text { Damage } \\
n(\%)\end{array}$ & $\begin{array}{l}\text { No damage } \\
n\end{array}$ & $\begin{array}{l}\text { Unknown } \\
n\end{array}$ \\
\hline Agaricia agaricites (Linnaeus, 1758) & 133 & 185 & $1.4 \pm 0.9$ & 117 & $61(52)$ & 56 & 68 \\
\hline Agaricia lamarcki Milne Edwards \& Haime, 1851 & 1 & 2 & & 2 & $1(50)$ & 1 & 0 \\
\hline Colpophyllia natans (Houttuyn, 1772) & 5 & 7 & $1.4 \pm 0.5$ & 6 & $4(67)$ & 2 & 1 \\
\hline Diploria labyrinthiformis (Linnaeus, 1758) & 4 & 4 & & 2 & $2(100)$ & 0 & 2 \\
\hline Eusmilia fastigiata (Pallas, 1766) & 4 & 4 & & 2 & $1(50)$ & 1 & 2 \\
\hline Madracis auretenra Locke, Weil \& Coates, 2007 & 79 & 221 & $2.9 \pm 2.9$ & 15 & $6(40)$ & 9 & 206 \\
\hline Madracis decactis (Lyman, 1859) & 6 & 9 & $1.5 \pm 0.8$ & 6 & $5(83)$ & 1 & 3 \\
\hline Madracis pharensis (Heller, 1868) & 12 & 21 & $1.8 \pm 0.8$ & 10 & $10(100)$ & 0 & 11 \\
\hline Meandrina meandrites (Linnaeus, 1758) & 2 & 2 & & 2 & $1(50)$ & 1 & 0 \\
\hline Millepora alcicornis Linnaeus, 1758 & 1 & 1 & & 0 & $0(0)$ & 0 & 1 \\
\hline Millepora complanata Lamarck, 1816 & 114 & 272 & $2.4 \pm 2.7$ & 146 & $35(24)$ & 111 & 126 \\
\hline Montastraea cavernosa (Linnaeus, 1767) & 19 & 27 & $1.4 \pm 0.7$ & 13 & $11(85)$ & 2 & 14 \\
\hline Orbicella annularis (Ellis \& Solander, 1786) & 245 & 414 & $1.7 \pm 1.3$ & 290 & $189(65)$ & 101 & 124 \\
\hline Orbicella faveolata (Ellis \& Solander, 1786) & 38 & 96 & $2.5 \pm 3.2$ & 29 & $20(69)$ & 9 & 67 \\
\hline Orbicella franksi (Gregory, 1895) & 69 & 149 & $2.2 \pm 1.8$ & 74 & $45(61)$ & 29 & 75 \\
\hline Porites astreoides Lamarck, 1816 & 274 & 559 & $2.0 \pm 1.8$ & 341 & $213(62)$ & 128 & 218 \\
\hline Porites porites (Pallas, 1766) & 21 & 50 & $2.4 \pm 2.5$ & 15 & $10(67)$ & 5 & 35 \\
\hline Pseudodiploria clivosa (Ellis \& Solander, 1786) & 3 & 6 & $2.0 \pm 1.0$ & 0 & $0(0)$ & 0 & 6 \\
\hline Pseudodiploria strigosa (Dana, 1846) & 110 & 432 & $3.9 \pm 5.2$ & 182 & $159(87)$ & 23 & 250 \\
\hline Siderastraea siderea (Ellis \& Solander, 1768) & 33 & 102 & $3.1 \pm 4.0$ & 41 & $30(73)$ & 11 & 61 \\
\hline Stephanocoenia intersepta (Lamarck, 1816) & 30 & 62 & $2.1 \pm 2.1$ & 27 & $26(87)$ & 4 & 32 \\
\hline Total & 1203 & 2625 & & 1323 & $829(63)$ & 494 & 1302 \\
\hline
\end{tabular}

Six species (bold script) with the highest numbers of worms analysed (each $n>50 ; n_{\text {tot }}$ present $=2011 ; n_{\text {tot }}$ analysed $=1150$ ) were selected for inter- and intraspecific comparisons of the occurrence of damage

Of all 1323 worms analysed, $829(62.6 \%)$ injured adjacent coral tissues with their opercula (Fig. 3; Table 2). The six host species with the highest numbers of associated worms, varied significantly in the proportions of worms causing operculum-induced injuries $(n=6$, $p<0.0001$, Fisher's exact test), ranging from $24 \%$ in the hydrocoral Millepora complanata to $87 \%$ in the scleractinian Pseudodiploria strigosa (Table 2), which showed, respectively, the lowest and highest damage levels $(p<0$. 0001, Post hoc tests with Bonferroni correction; Fig. 4, Table 3).

A large portion (78\%) of the opercula in worms infesting the six host species was covered by filamentous turf algae (Fig. 3), which did not differ significantly in damage level compared with those without algae (Fig. 4; Fisher's exact test).

\section{Discussion}

Five scleractinian coral species and one milleporid showed a strong interspecific variation in damage caused by the opercula of Spirobranchus worms. The lowest damage shown by Millepora complanata (Fig. 3a) in comparison with the scleractinians may be related to its thin coenosarc, as well as to its different skeleton anatomy (pores instead of protruding calices), thereby showing a higher tolerance to physical disturbance (Lewis 1989, 2006). Pseudodiploria strigosa, a common host for $S$. giganteus (Hunte et al. 1990; Marsden et al 1990), shows the highest frequency of worm-induced injuries. This coral species is much under attack by corallivorous Coralliophila snails in Curaçao (Potkamp et al. 2017a, b), which also cause abrasions on the coral surface. Since Spirobranchus larvae settle most easily on abraded coral surface (Hutchings 1986), this may facilitate further damage caused by the worms. 



Fig. 2 Spirobranchus giganteus tubes on corals of various host species (arrows) at Curaçao. a Agaricia agaricites: tube (1) completely embedded (2) mostly embedded (3) largely exposed and partly covered by algae. b Porites porites: tubes covered by red crustose cor-

The lack of influence of the epibiotic algae on Spirobranchus opercula is not consistent with previous studies on the impact of turf algae on corals (McCook et al 2001; Swierts and Vermeij 2016; Longo and Hay 2017). It is partly consistent with observations on Indo-Pacific reefs, in which such epibiotic algae increase damage in corals of two species of Porites but not in two of Montipora (Hoeksema et al. 2018, 2019). Therefore, our results suggest that the opercula themselves are the single cause of coral damage in Curaçao, although this does not imply that turf algae by themselves cannot cause damage to corals in the Caribbean (Vermeij et al. 2010; Wild et al. 2014). alline algae. c Orbicella annularis: high density of exposed worm tubes. Pseudodiploria strigosa (d) and Tubastraea coccinea (e): exposed worm tube with turf algae. Worm tubes not overgrown by the host may be situated in coral surface depressions $(\mathbf{c}, \mathbf{d})$

Regeneration of coral wounds depends on their size, shape and position, but also on the coral species, shape, size and depth (Bak et al. 1977; Bak and Steward-Van Es 1980; Meesters et al. 1996, 1997a, b). Damage in corals caused by Spirobranchus may be difficult to heal, which becomes obvious when worm tubes cannot be overgrown by coral tissues (Fig. 2) or when vacated tubes become inhabited by other organisms (Schuhmacher 1977; Hutchings 1986; Böhm and Hoeksema 2017). Such damage may also cause the corals to become more susceptible to diseases (Katz et al. 2014; Lamb et al. 2014). 

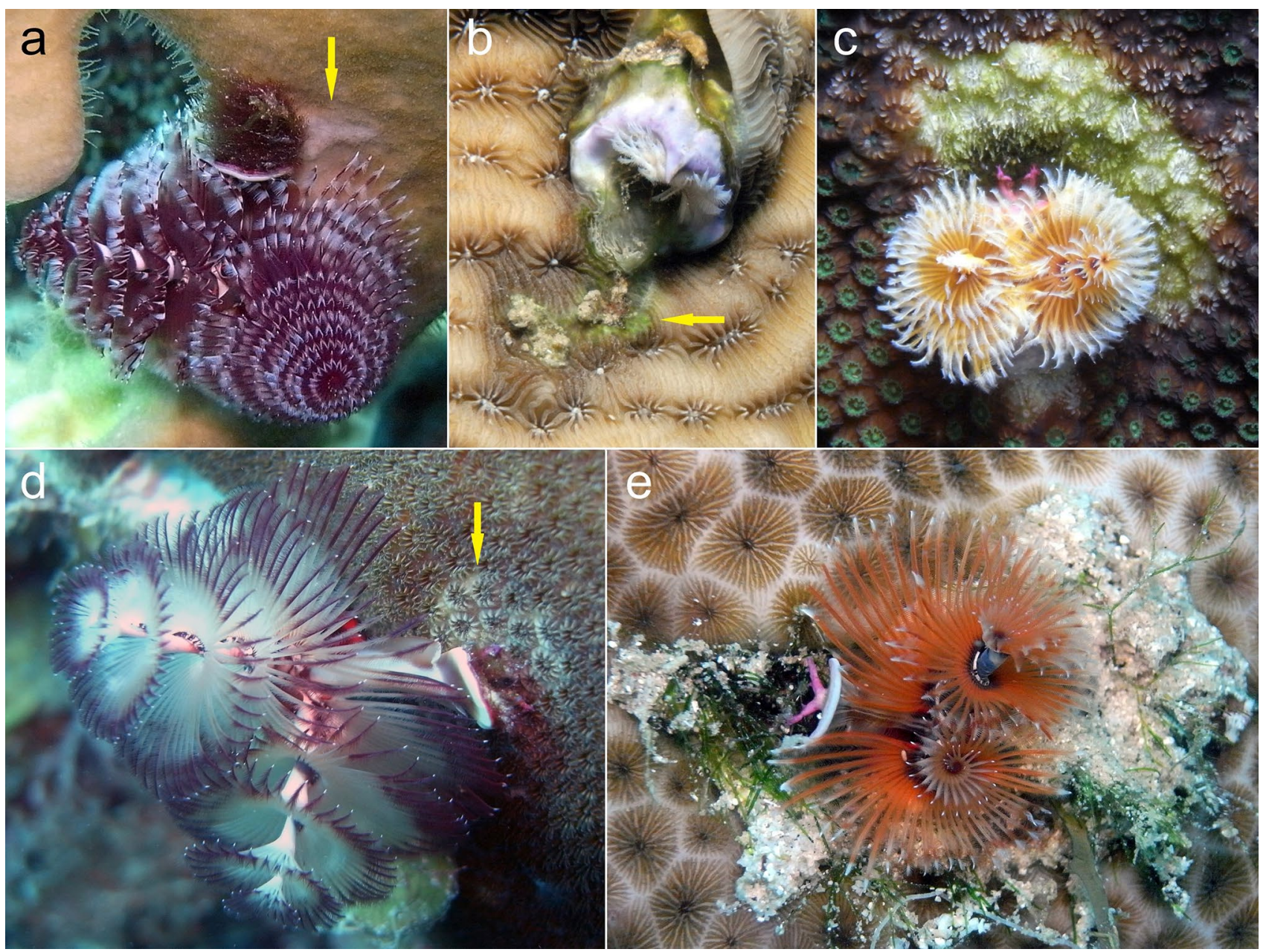

Fig. 3 Coral injuries beneath $S$. giganteus opercula on various host species (arrows) at Curaçao. a Millepora complanata. b Agaricia lamarcki. c Orbicella faveolata. d Orbicella annularis. e Siderastrea siderea

Coral-associated Spirobranchus are often reported as being beneficious for the host, by providing protection against predators or by enhancing water circulation around the coral polyps (DeVantier et al. 1986; Ben-Tzvi et al. 2006). Each of these advantages appear to be small in scale and reported once, with the first one being cited repeatedly (Nygaard 2008; Rowley 2008; Montano et al. 2017; Perry et al. 2018a; Montalbetti et al. 2019). Conversely, our present study and previous results (Borger 2005; Samimi Namin et al. 2010; Hoeksema et al. 2018, 2019) reveal a relevant and widespread negative impact of Spirobranchus worms on their hosts. It is remarkable that damage caused by worm opercula at Curaçao in the Caribbean $(63 \%, n=1323)$ was found to be much more frequent than at Koh Tao in the Gulf of Thailand (21\%, $n=749$; Hoeksema et al. 2019). This constitutes a significant difference $(p<0.0001$, Fisher's exact test), for which various hypotheses can be given that are either related to environmental differences or to the various worm and coral species involved. For instance, opercula in the Caribbean Spirobranchus giganteus are generally larger and more heavily branched than those of $S$. corniculatus (Grube, 1862), the species most commonly found in the Indo-Pacific (ten Hove 1970; Willette et al. 2015; Perry et al. 2018b). Polyp morphology and the position of the worm in relation to the coral's surface may be factors that can affect the damaging effect of the opercula (Hoeksema et al. 2019).

Therefore, further studies must address the balance between positive and negative impacts of Spirobranchus worms on their host corals, enabling a decision whether their relation must be considered amensalistic, in which the worms harm the coral but are not harmed themselves, or mutualistic, in which both partners eventually benefit, and/or in which circumstances these two strategies prevail. Such a knowledge may be relevant for the management and preservation of coral reefs if, for instance, external circumstances (e.g., pollution, turbidity) may weaken the coral's resistance, thus inclining the response of the worms towards a more parasitic behaviour. 
Fig. 4 Comparison of proportions of Spirobranchus opercula causing coral damage with or without algae (Fisher's exact test) across six host coral species at Curaçao (ns not significant)

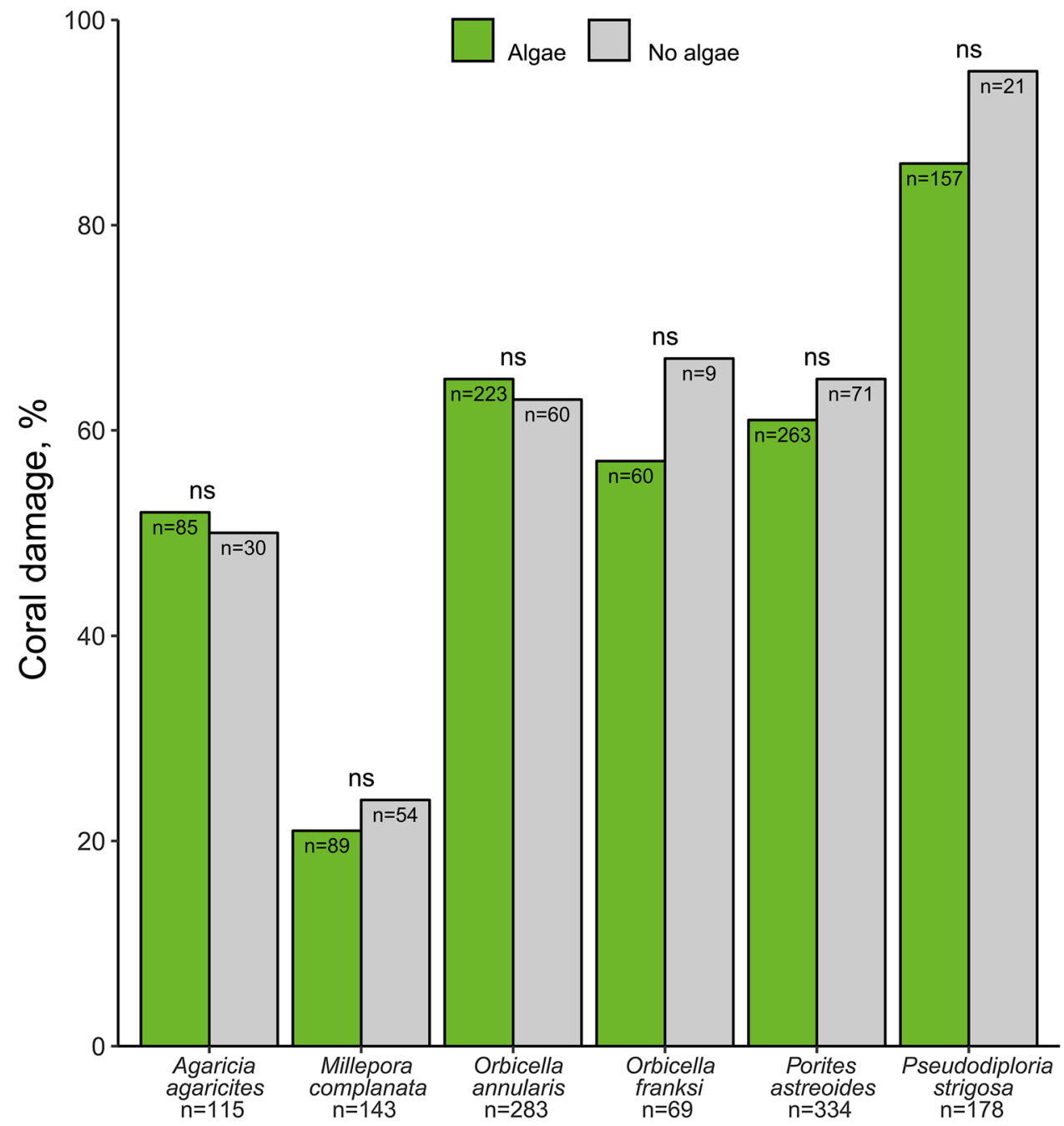

Table 3 Post hoc results with Bonferroni correction of the Fisher's exact test for differences in opercula-induced damage between two host coral species

\begin{tabular}{llllll}
\hline Species & Millepora complanata & Agaricia agaricites & Orbicella annularis & Orbicella franksi & Porites astreoides \\
\hline Agaricia agaricites & $p<0.0001$ & & & \\
Orbicella annularis & $p<0.0001$ & $\mathrm{~ns}$ & $\mathrm{~ns}$ & \\
Orbicella franksi & $p<0.0001$ & $\mathrm{~ns}$ & $\mathrm{~ns}$ & $\mathrm{~ns}$ & \\
Porites astreoides & $p<0.0001$ & $\mathrm{~ns}$ & $p<0.0001$ & $p<0.0001 \quad p<0.0001$ \\
Pseudodiploria strigosa & $p<0.0001$ & $p<0.0001$ & & \\
\hline
\end{tabular}

Acknowledgements We thank staff of CARMABI (Curaçao) for hospitality and logistic support, and Dr. Mark Vermeij for his constructive comments on an early draft of the ms. We also thank two reviewers and the editor for their help in improving this paper.

Funding The second and third authors received financial support from the Jan Joost ter Pelkwijk Fund and the Alida M. Buitendijk Fund at Naturalis.

\section{Compliance with ethical standards}

Conflict of interest All authors declare that they have no conflict of interest.

Ethical approval All applicable international, national, and/or institutional guidelines for the care and use of animals were followed. 
Open Access This article is distributed under the terms of the Creative Commons Attribution 4.0 International License (http://creativeco mmons.org/licenses/by/4.0/), which permits unrestricted use, distribution, and reproduction in any medium, provided you give appropriate credit to the original author(s) and the source, provide a link to the Creative Commons license, and indicate if changes were made.

\section{References}

Bak RPM, Brouns JJWM, Heys FML (1977) Regeneration and aspects of spatial competition in the scleractinian corals Agaricia agaricites and Montastrea annularis. Proc 3rd Int Coral Reef Symp 3:143-149

Bak RPM, Steward-van Es Y (1980) Regeneration of superficial damage in the Scleractinian corals Agaricia agaricites f. purpurea and Porites astreoides. Bull Mar Sci 30:883-887

Ben-Tzvi O, Einbinder S, Brokovich E (2006) A beneficial association between a polychaete worm and a scleractinian coral? Coral Reefs 25:98

Böhm T, Hoeksema BW (2017) Habitat selection of the coral-dwelling spinyhead blenny, Acanthemblemaria spinosa, at Curaçao, Dutch Caribbean. Mar Biodivers 47:17-25

Borger JL (2005) Dark spot syndrome: a scleractinian coral disease or a general stress response? Coral Reefs 24:139-144

Clarke RD, Tyler JC (2003) Differential space utilization by male and female spinyhead blennies, Acanthemblemaria spinosa (Teleostei: Ceanopsidae). Copeia 2003:241-247

DeVantier LM, Reichelt RE, Bradbury RH (1986) Does Spirobranchus giganteus protect host Porites from predation by Acanthaster planci: predator pressure as a mechanism of coevolution? Mar Ecol Prog Ser 32:307-310

García-Hernández JE, Hoeksema BW (2017) Sponges as secondary hosts for Christmas tree worms at Curaçao. Coral Reefs 36:1243

Hoeksema BW, ten Hove HA (2014) First record of a Christmas tree worm in a mushroom coral (Loyalty Islands, Southwest Pacific). Coral Reefs 33:717

Hoeksema BW, ten Hove HA (2017a) The invasive sun coral Tubastraea coccinea hosting a native Christmas tree worm at Curaçao, Dutch Caribbean. Mar Biodivers 47:59-65

Hoeksema BW, ten Hove HA (2017b) Attack on a Christmas tree worm by a Caribbean sharpnose puffer fish at St. Eustatius, Dutch Caribbean. Bull Mar Sci 93:1023-1024

Hoeksema BW, Lau YW, ten Hove HA (2015) Octocorals as secondary hosts for Christmas tree worms off Curaçao. Bull Mar Sci 91:489-490

Hoeksema BW, ten Hove HA, Berumen ML (2016) Christmas tree worms evade smothering by a coral-killing sponge in the Red Sea. Mar Biodivers 46:15-16

Hoeksema BW, van Beusekom M, ten Hove HA, Ivanenko VN, van der Meij SET, van Moorsel GWNM (2017) Helioseris cucullata as a host coral at St. Eustatius, Dutch Caribbean. Mar Biodivers 47:71-78

Hoeksema BW, ten Hove HA, Berumen ML (2018) A three-way association causing coral injuries in the Red Sea. Bull Mar Sci 94:1525-1526

Hoeksema BW, van der Schoot RJ, Wels D, Scott C, ten Hove HA (2019) Filamentous turf algae on tube worms intensify damage in massive Porites corals. Ecology. https://doi.org/10.1002/ ecy. 2668

Humann P, DeLoach N (2013) Reef coral identification: Florida, Caribbean, Bahamas, 3rd edn. New World Publications, Jacksonville

Hunte W, Conlin BE, Marsden JR (1990) Habitat selection in the tropical polychaete Spirobranchus giganteus. I. Distribution on corals. Mar Biol 104:87-92
Hutchings PA (1986) Biological destruction of coral reefs-a review. Coral Reefs 4:239-252

Hutchings PA (2011) Bioerosion. In: Hopley D (ed) Encyclopedia of modern coral reefs-structure, form and processes. Springer, Berlin, pp 139-156

Katz S, Pollock FJ, Bourne D, Willis B (2014) Crown-of-thorns starfish predation and physical injuries promote brown band disease on corals. Coral Reefs 33:705-716

Lamb JB, True JD, Piromvaragorn S, Willis BL (2014) Scuba diving damage and intensity of tourist activities increases coral disease prevalence. Biol Conserv 178:88-96

Lewis JB (1989) The ecology of Millepora-a review. Coral Reefs 8:99-107

Lewis JB (2006) Biology and ecology of the hydrocoral Millepora on coral reefs. Adv Mar Biol 50:1-55

Longo GO, Hay ME (2017) Seaweed allelopathy to corals: are active compounds on, or in, seaweeds? Coral Reefs 36:247-253

Marsden JRB, Conlin E, Hunte W (1990) Habitat selection in the tropical polychaete Spirobranchus giganteus. 2. Larval preferences for corals. Mar Biol 104:93-99

Martin D, Britayev TA (2018) Symbiotic polychaetes revisited: an update of the known species and relationships (1998-2017). Oceanogr Mar Biol Annu Rev 56:371-448

McCook LJ, Jompa J, Diaz-Pulido G (2001) Competition between corals and algae on coral reefs: a review of available evidence and mechanisms. Coral Reefs 19:400-417

McDonald JH (2014) Handbook of biological statistics, 3rd edn. Sparky House Publishing, Baltimore

Meesters EH, Wesseling I, Bak RPM (1996) Partial mortality in three species of reef-building corals (Scleractinia) and the relation with colony morphology. Bull Mar Sci 58:838-852

Meesters EH, Pauchli W, Bak RPM (1997a) Predicting regeneration of physical damage on a reef-building coral by regeneration capacity and lesion shape. Mar Ecol Prog Ser 146:91-99

Meesters EH, Wesseling I, Bak RPM (1997b) Coral colony tissue damage in six species of reef-building corals: partial mortality in relation with depth and surface area. J Sea Res 37:131-144

Montalbetti E, Saponari L, Montano S, Maggioni D, Dehnert I, Galli P, Seveso D (2019) New insights into the ecology and corallivory of Culcita sp. (Echinodermata: Asteroidea) in the Republic of Maldives. Hydrobiologia 827:353-365

Montano S, Fattorini S, Parravicini V, Berumen ML, Galli P, Maggioni D, Arrigoni R, Seveso D, Strona G (2017) Corals hosting symbiotic hydrozoans are less susceptible to predation and disease. Proc R Soc B 284:20172405

Nishi E, Kikuchi T (1996) Preliminary observation of the tropical serpulid Spirobranchus giganteus corniculatus Pallas. Publ Amakusa Mar Biol Lab Kyushu Univ 12:45-54

Nishi E, Nishihira M (1996) Age-estimation of the Christmas tree worm Spirobranchus giganteus (Polychaeta, Serpulidae) living buried in the coral skeleton from the coral-growth band of the host coral. Fish Sci 62:400-403

Nygaard L (2008) Size distribution of Spirobanchus giganteus in Bonaire: is there a benefit of recruitment to live coral? Physis 3:25-30

Perry O, Sapir Y, Perry G, ten Hove H, Fine M (2018a) Substrate selection of Christmas tree worms (Spirobranchus spp.) in the Gulf of Eilat, Red Sea. J Mar Biol Assoc UK 98:791-799

Perry O, Bronstein O, Simon-Blecher N, Atkins A, Kupriyanova E, ten Hove H, Levy O, Fine M (2018b) On the genus Spirobranchus (Annelida, Serpulidae) from the northern Red Sea, and a description of a new species. Invertebr Syst 32:605-626

Pezner AK, Lim AR, Kang JJ, Armenta TC, Blumstein DT (2017) Hiding behavior in Christmas tree worms on different time scales. Behav Ecol 28:154-163 
Potkamp G, Vermeij MJA, Hoeksema BW (2017a) Host-dependent variation in density of corallivorous snails (Coralliophila spp.) at Curaçao, southern Caribbean. Mar Biodivers 47:91-99

Potkamp G, Vermeij MJA, Hoeksema BW (2017b) Genetic and morphological variation in corallivorous snails (Coralliophila spp.) living on different host corals at Curaçao, southern Caribbean. Contrib Zool 86:111-144

Rowley SJ (2008) A critical evaluation of the symbiotic association between tropical tube-dwelling Polychaetes and their hermatypic coral hosts, with a focus on Spirobranchus giganteus (Pallas, 1766). Plymouth Stud Sci 1:335-353

Samini Namin K, Risk MJ, Hoeksema BW, Zohari Z, Rezai H (2010) Coral mortality and serpulid infestations associated with red tide, in the Persian Gulf. Coral Reefs 29:509

Schuhmacher H (1977) A hermit crab, sessile on corals, exclusively feeds by feathered antennae. Oecologia 27:371-374

Swierts T, Vermeij MJA (2016) Competitive interactions between corals and turf algae depend on coral colony form. PeerJ 4:e1984

ten Hove HA (1970) Serpulinae (Polychaeta) from the Caribbean: I The genus Spirobranchus. Stud Fauna Curaçao 32:1-57 van der Schoot R, Scott CM, ten Hove HA, Hoeksema BW (2016) Christmas tree worms as epibionts of giant clams at Koh Tao, Gulf of Thailand. Mar Biodivers 46:751-752

Vermeij MJA, van Moorselaar I, Engelhard S, Hörnlein C, Vonk SM, Visser PM (2010) The effects of nutrient enrichment and herbivore abundance on the ability of turf algae to overgrow coral in the Caribbean. PLoS ONE 5:e14312

Wild C, Jantzen C, Kremb SG (2014) Turf algae-mediated coral damage in coastal reefs of Belize, Central America. PeerJ 2:e571. https ://doi.org/10.7717/peerj.571

Willette DA, Iñiguez AR, Kupriyanova EK, Starger CJ, Vartman T, Toha AH, Maralit BA, Barber PH (2015) Christmas tree worms of Indo-Pacific coral reefs: untangling the Spirobranchus corniculatus (Grube, 1862) complex. Coral Reefs 34:899-904

Publisher's Note Springer Nature remains neutral with regard to jurisdictional claims in published maps and institutional affiliations. 